\title{
Mechanism of Action of Pentagastrin on the
}

\section{Lower Esophageal Sphincter}

\author{
Robert Zwick, Kenneth L. Bowes, E. E. Daniel, and S. K. Sarna \\ From the Surgical Medical Research Institute, University of Alberta, \\ Edmonton, Alberta, Canada
}

\begin{abstract}
A B S TRACT The effect of pentagastrin on lower esophageal sphincter (LES) pressure has been studied in trained, unanesthetized dogs. LES pressure was monitored by an infusion manometric technique. Increasing doses of pentagastrin up to $3 \mu \mathrm{g} / \mathrm{kg}$ given as an i.v. bolus resulted in increasing rises in LES pressure; larger doses resulted in a lesser effect of shorter duration. Increasing i.v. boluses of methacholine produced greater increases in LES pressure up to a maximum of $5 \mu \mathrm{g} / \mathrm{kg}$; higher doses had similar effects. Atropine (50-100 $\mathrm{mg} /$ $\mathrm{kg}$ ) slightly diminished the response of the LES to 2 or $6 \mu \mathrm{g} / \mathrm{kg}$ of pentagastrin. In large doses $(500-2,000 \mu \mathrm{g} /$ $\mathrm{kg}$ ), atropine did not diminish the response to pentagastrin and prolonged the response of $6 \mu \mathrm{g} / \mathrm{kg}$ pentagastrin. Hexamethonium (2 $\mathrm{mg} / \mathrm{kg}$ i.v.) depressed the peak response to $3 \mu \mathrm{g} / \mathrm{kg}$ pentagastrin slightly but the response to $6 \mu \mathrm{g} / \mathrm{kg}$ was increased and prolonged. Propranolol ( $2 \mathrm{mg} / \mathrm{kg}$ i.v.) significantly prolonged the effect of $6 \mu \mathrm{g} / \mathrm{kg}$ pentagastrin on the LES. We conclude that the stimulatory effect of pentagastrin is mainly due to a direct action on the LES. A lesser stimulatory effect is due to an action on preganglionic cholinergic neurons. Large doses of pentagastrin have both stimulatory and inhibitory effects. The inhibitory effect is mediated at least in part via preganglionic neurons acting through adrenergic receptors. Ganglionic transmission of the effect may be through muscarinic as well as nicotinic receptors.
\end{abstract}

\section{INTRODUCTION}

Gastrin and its synthetic analogue pentagastrin have been shown to increase lower esophageal sphincter $(\mathrm{LES})^{1}$ pressure in anesthetized dogs, North American

Received for publication 4 April 1975 and in revised form 5 February 1976.

${ }_{1}$ Abbreviation used in this paper: LES, lower esophageal sphincter. opossums, normal man, and in patients with reflux, achalasia, and Zollinger-Ellison syndrome (1-6).

In all of these studies, the dose-response curve showed an increased response to increasing doses up to a peak response; then further increases in dose caused a diminished response. The exact mechanism producing diminished responses to high doses is not understood. The mechanism whereby gastrin produces LES contraction may be relevant to this inhibition at high doses.

In a variety of gastrointestinal muscles, gastrin has been suggested to act by releasing acetylcholine. This suggestion is compatible with the finding that stimulatory effects on antral and jejunal contractions in dogs and in guinea pig ileum are antagonized by atropine and tetrodotoxin (7-10). There is some disagreement about whether these effects are blocked by hexamethonium; they were not blocked in studies using in vitro strips (7, $8,10,11)$ but were blocked in studies of the in vitro dog stomach (9).

Lipshutz et al. (11) found that the effect of gastrin on isolated opossum LES muscle strips was also blocked by atropine and tetrodotoxin, but hexamethonium depressed the response minimally. The current hypothesis is that gastrin acts either on pre- or postganglionic parasympathetic nerves in Auerbach's plexus to release acetylcholine, causing contraction of circular muscle. Pentagastrin is presumed to act on the same receptors and by the same mechanism as gastrin. In this study we have attempted to analyse the mechanisms underlying pentagastrin's action on the LES by selectively stimulating or inhibiting links in the chain of neurons and synapses through which the effects of pentagastrin are thought to be mediated.

\section{METHODS}

Three adult mongrel dogs, weighing 25,23 , and $21 \mathrm{~kg}$, were used throughout the experiments. Each dog was trained to lie quietly on a specially constructed table with a nylon bone tied in its mouth and to swallow a catheter assembly. 
The bone had a hole in it through which the six polyvinyl catheter assembly was passed into the dog's mouth. The training period took about $6 \mathrm{wk}$. Before all experiments, food was withheld from the dog for $20 \mathrm{~h}$. Normal saline was infused slowly into the right saphenous vein through a 20-gauge Medicut (Sherwood Medical Industries, Inc. St. Louis, Mo.).

The swallowed catheter assembly (outside diameter 5 $\mathrm{mm}$ ) was made from six $75-\mathrm{cm}$ lengths of Becton-Dickinson vinyl tubing 6179, Becton, Dickinson \& Co., Waltham Mass. (inside diameter 0.044 inch, outside diameter 0.065 inch) glued together with tetrahydrofuran (J. T. Baker Chemical Co., Phillipsburg, N. J.). The distal end of the assembly was sealed with heat-shrink tubing. Each catheter has a hole ( 0.044 inch diameter) for perfusion; four such holes were spaced evenly over $14 \mathrm{~mm}$ of the assembly and all faced in the same direction; the other two holes were $5 \mathrm{~cm}$ above and $5 \mathrm{~cm}$ below this series.

Each catheter was connected to a Statham pressure transducer (series P23, Statham Instruments Div., Gould Inc., Oxnard, Calif.) and constantly infused $(1.9 \mathrm{ml} / \mathrm{min})$ with water. The assembly could respond to pressure changes from 0 to $100 \mathrm{~mm} \mathrm{Hg}$ in less than $3 \mathrm{~s}$. The pressure transducers were connected to a Beckman type $\mathrm{R}$ Dynograph (Beckman Instruments, Inc., Fullerton, Calif.).

At the start of an experiment the assembly was placed in the stomach. After a pull-through was done to locate the LES, the four middle recording tubes were positioned in the LES so that the point of respiratory reversal was straddled. The other two catheters then recorded pressure in the distal esophagus and stomach. Two criteria had to be met for the subsequent results to be acceptable: the presence of a steady LES base-line pressure for at least $2 \mathrm{~min}$ before the administration of a drug; and no evidence of a tube moving out of the LES during the recording of the stimulated LES pressure. Such movement could be recognized by changes in the direction of the respiratory deflection. These conditions were met in about two-thirds of all attempted experiments. Resting pressure was measured as the mean of end-inspiratory and end-expiratory deflection. The tube recording maximal resting pressure at any time was read as sphincter pressure.

Each drug agonist or dose of a drug agonist was given on a separate day, sometimes preceded by an antagonist. Dogs were used in rotation so that each animal was used a similar number of times for each comparison. Pentagastrin and methacholine were used as agonists, atropine, hexamethonium, and propranolol as antagonists; doses were expressed in terms of their salts (methacholine bromide, Sigma Chemical Co., St. Louis, Mo.; atropine sulfate, British Drug Houses Ltd., Toronto, Ont.; propranolol hydrochloride, Ayerst Laboratories, Div. of American Home Products Corporation, New York; hexamethonium methylsulfate, Sigma). All bolus doses of agonists were given over 2-4 s.

Response of the LES was quantitated in terms of pressures at various times after drug administration. Peak responses and duration of response (to $150 \%$ of the predrug pressure) were determined. In some cases we did not wait for return of LES pressure to predrug levels, since the recovery seemed usually to be exponential and thus slow near the base line; furthermore, there were apparently small random fluctuations in the base line in control and experimental runs. The use of recovery to $100 \%$ of control LES pressure would have introduced large experimental errors in the evaluation of duration of action, and recovery to $150 \%$ was adopted as an alternative.

\section{RESULTS}

The effect of an i.v. bolus of pentagastrin. Pentagastrin rapidly increased LES resting pressure; the peak occurred after $45-60 \mathrm{~s}$. Thereafter the pressure fell towards base line (Fig. 1). Peak responses were 112.2 \pm 4.7, 74.7 \pm 9.3 , and $76.2 \pm 5.1$ (mean \pm SEM) at 3, 4, and $6 \mu \mathrm{g} / \mathrm{kg}$. Values after $3 \mu \mathrm{g} / \mathrm{kg}$ were significantly lower $(P<0.05)$. Furthermore the duration of the increased pressure of the LES was appreciably shorter after high doses of pentagastrin $(P<0.05)$ (Fig. 2). In about $20 \%$ of the experiments, spontaneous phasic contractions of the LES were observed during the basal period but disappeared after pentagastrin was administered. No phasic contractions were superimposed on the LES pressure increase produced by pentagastrin.

The effect of atropine. Doses of 50 or $100 \mu \mathrm{g} / \mathrm{kg}$ of atropine intravenously had similar effects and decreased LES pressure from 37 to $19 \mathrm{~mm} \mathrm{Hg}$ in $60 \mathrm{~s}(P<0.01)$. $500-2,000 \mu \mathrm{g} / \mathrm{kg}$ of atropine i.m. had a similar effect, a decrease in LES pressure from 39 to $20 \mathrm{~mm} \mathrm{Hg}$ over $20 \mathrm{~min}$. The small doses of atropine were chosen because they completely block the effects of an i.v. bolus of $5 \mu \mathrm{g} / \mathrm{kg}$ of methacholine. The larger doses were chosen because acetylcholine may be released from nerve varicosities very close to muscle in the LES (Daniel, E. E., unpublished observations), and thus higher doses might be required to inhibit the response to released acetylcholine than to infused methacholine. Pentagastrin

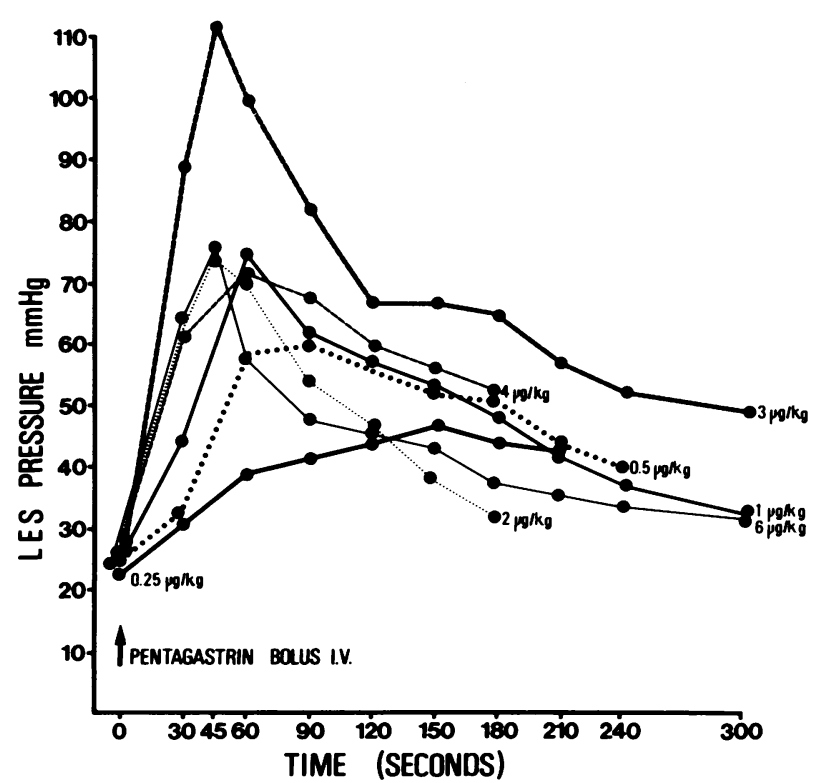

FIGURE 1 The effect of an i.v. bolus containing varying amounts of pentagastrin on LES resting pressure. Each point represents the mean of at least 20 studies. A maximal effect was observed after $45 \mathrm{~s}$ with $3 \mu \mathrm{g} / \mathrm{kg}$. Doses greater than that resulted in a lesser response. 


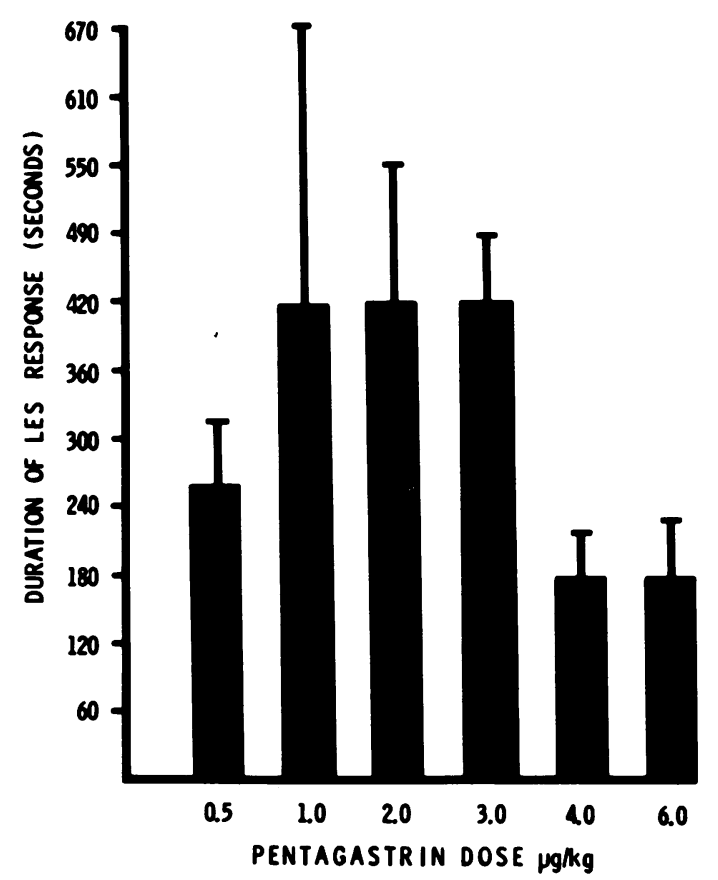

Figure 2 Time for LES resting pressure to return to $150 \%$ of base-line pressure after an i.v. bolus of pentagastrin $($ mean $\pm S D)$. Higher doses of pentagastrin had a briefer duration of action than moderate doses.

was, however, still capable of elevating LES pressure (e.g. $2 \mu \mathrm{g} / \mathrm{kg}$ raised the LES pressure from $21.4 \pm 1.6$ to 53.0 \pm 7.8$)(P<0.001)$; the peak response of the LES to an i.v. bolus of $2 \mu \mathrm{g} / \mathrm{kg}$ pentagastrin was slightly but significantly diminished $(P<0.005)$ by low doses $(50$ $100 \mathrm{\mu g} / \mathrm{kg}$ ) of atropine, but a $150 \%$ increase in pressure was still observed. After high doses $(500-2,000 \mu \mathrm{g} / \mathrm{kg}$ ) of atropine, inhibition of pentagastrin's effect on the LES was not observed (Fig. 3A).

The effect of $6 \mu \mathrm{g} / \mathrm{kg}$ pentagastrin on the LES was also diminished by $50-100 \mu \mathrm{g} / \mathrm{kg}$ of atropine. A significant increase in sphincter pressure was however still observed (Fig. 3B). No significant inhibition of the peak response was observed, however, after high doses of atropine, but the peak response occurred later than in the control. The period of maximum effect of $6 \mu \mathrm{g} / \mathrm{kg}$ pentagastrin was considerably prolonged by higher doses of atropine, in that there was no significant decrease in pressure from the peak response $2 \mathrm{~min}$ after injection; such a decrease occurred in other instances after injection of a high dose of pentagastrin.

The effect of methacholine. An intravenous bolus of methacholine rapidly increased LES pressure; the maximal effect occurred at 45 or $60 \mathrm{~s}$. Unlike the response to pentagastrin, each dose increment up to $5 \mu \mathrm{g} / \mathrm{kg}$ was followed by an increased response by the LES. Greater doses than $5 \mu \mathrm{g} / \mathrm{kg}$ did not produce a diminished re- sponse (Fig. 4). The duration of the response was also increased as the dose increased (Fig. 5). Thus, a cholinergic agonist that produced increases in LES pressure as large as those in response to pentagastrin did not produce diminished responses of higher doses; hence, the effects of gastrin did not result from inherent peculiarities of the responding system.

A large additional dose of pentagastrin $(6 \mu \mathrm{g} / \mathrm{kg})$ resulted in no change in peak response to 3 or $12 \mu \mathrm{g} / \mathrm{kg}$ of methacholine. This dose of pentagastrin had no effect on the falloff of the response to $12 \mu \mathrm{g} / \mathrm{kg}$ of methacholine. When it was added to $3 \mu \mathrm{g} / \mathrm{kg}$ of methacholine, the falloff was less abrupt (Fig. 6). Thus it was not possible to unmask inhibition of LES pressure by large doses of pentagastrin by administering it at time of peak response to a cholinergic agonist.

The effect of hexamethonium. Hexamethonium depressed the peak response to $3 \mu \mathrm{g} / \mathrm{kg}$ pentagastrin but had no significant effect on the response to $6 \mu \mathrm{g} / \mathrm{kg}$ (Fig. 7A and B). Hexamethonium also resulted in a slightly slower decline in the response to $6 \mu \mathrm{g} / \mathrm{kg}$ of pentagastrin. It had no effect on the falloff after $3 \mu \mathrm{g} / \mathrm{kg}$ of pentagastrin.

The effect of propranolol. Propranolol did not effect resting LES pressure when given alone. Peak response of $6 \mu \mathrm{g} / \mathrm{kg}$ of pentagastrin was not altered by propranolol. However, there was significant prolongation of the effect (Fig. 8); the greater response to pentagastrin after $60 \mathrm{~s}$ in propranolol-treated animals was too large to be completely explained by the higher initial pressure in these animals compared to controls.

\section{DISCUSSION}

In these experiments on i.v. bolus of $3 \mu \mathrm{g} / \mathrm{kg}$ of pentagastrin produced a peak stimulatory effect on the canine LES. With doses greater than $3 \mu \mathrm{g} / \mathrm{kg}$, the response was less and falloff more rapid. It is difficult to reconcile these findings with the concept that pentagastrin acts simply on pre- or postganglionic cholinergic neurons to release acetylcholine, as has been suggested by several workers $(8,10,11)$. Such a concept would require the existence of both stimulatory, more sensitive, and inhibitory, less sensitive, cholinergic receptors in the muscle of the LES. Moreover, methacholine, an analogue of acetylcholine, acting on the same receptors on smooth muscle, should have a similar effect on the LES. Instead the dose-response curve to methacholine was a typical hyperbolic one. Higher doses never gave a lesser effect, either in peak response or duration of response.

We conclude that the diminished response to high doses of pentagastrin resulted either from activation of an inhibitory mechanism or blocking of the excitatory mechanism by high doses. 


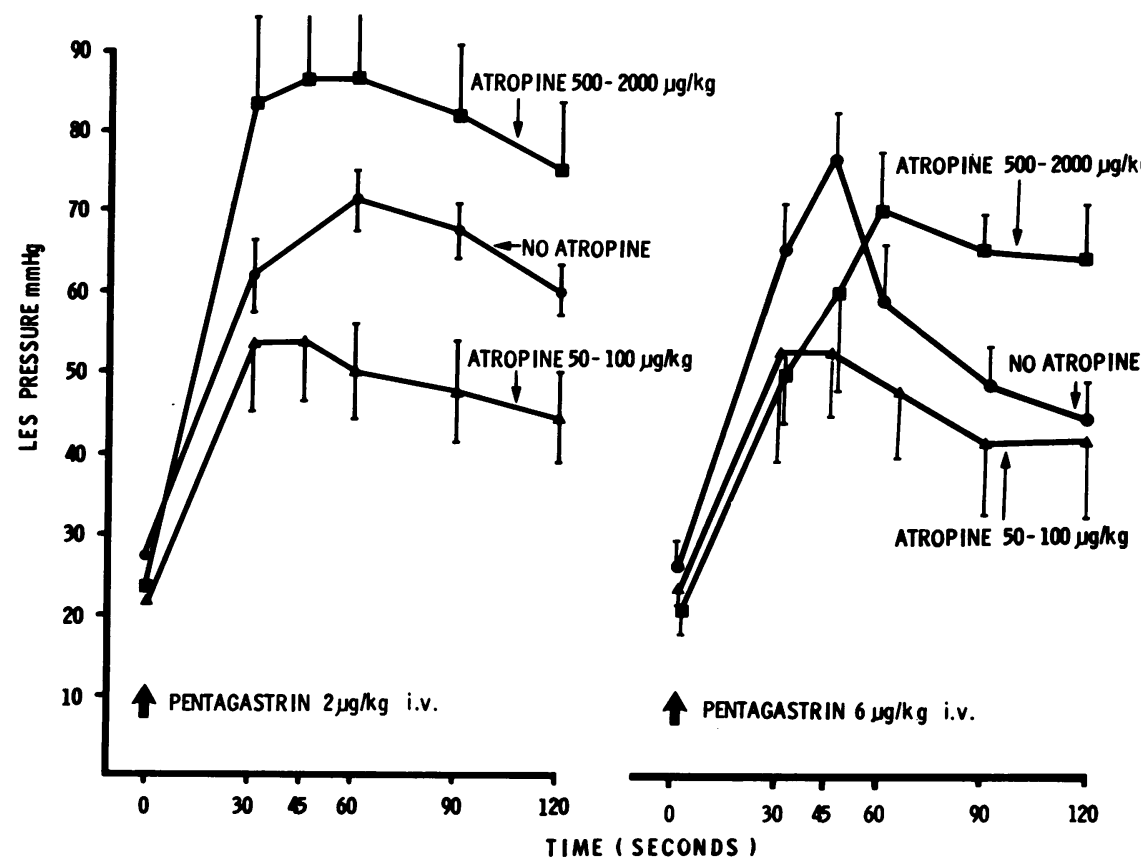

FIGURE 3 A. The effect of $2 \mu \mathrm{g} / \mathrm{kg}$ i.v. bolus of pentagastrin on LES pressure after high $(500-2,000 \mu \mathrm{g} / \mathrm{kg})$ and low $(50-100 \mu \mathrm{g} / \mathrm{kg})$ doses of atropine (mean \pm SEM). Each point represents the mean \pm SEM of at least 11 studies. Pentagastrin significantly increased LES pressure after atropinization $(P<0.001)$. B. The effect of $6 \mu \mathrm{g} / \mathrm{kg}$ i.v. bolus of pentagastrin on LES pressure after high $(500-2,000 \mu \mathrm{g} / \mathrm{kg}$ ) and low $(50-100 \mu \mathrm{g} / \mathrm{kg}$ ) doses of atropine (mean \pm SEM). A significant inhibition of peak response to pentagastrin was observed after $50-100$ $\mu \mathrm{g} / \mathrm{kg}$ of atropine $(P<0.05)$. Duration of response after this dose was not affected. $500-2,000$ $\mu \mathrm{g} / \mathrm{kg}$ of atropine delayed the peak response but did not diminish it. Duration of response was considerably prolonged $(P<0.05$ at $90 \mathrm{~s}$ and $<0.025$ at $120 \mathrm{~s})$.

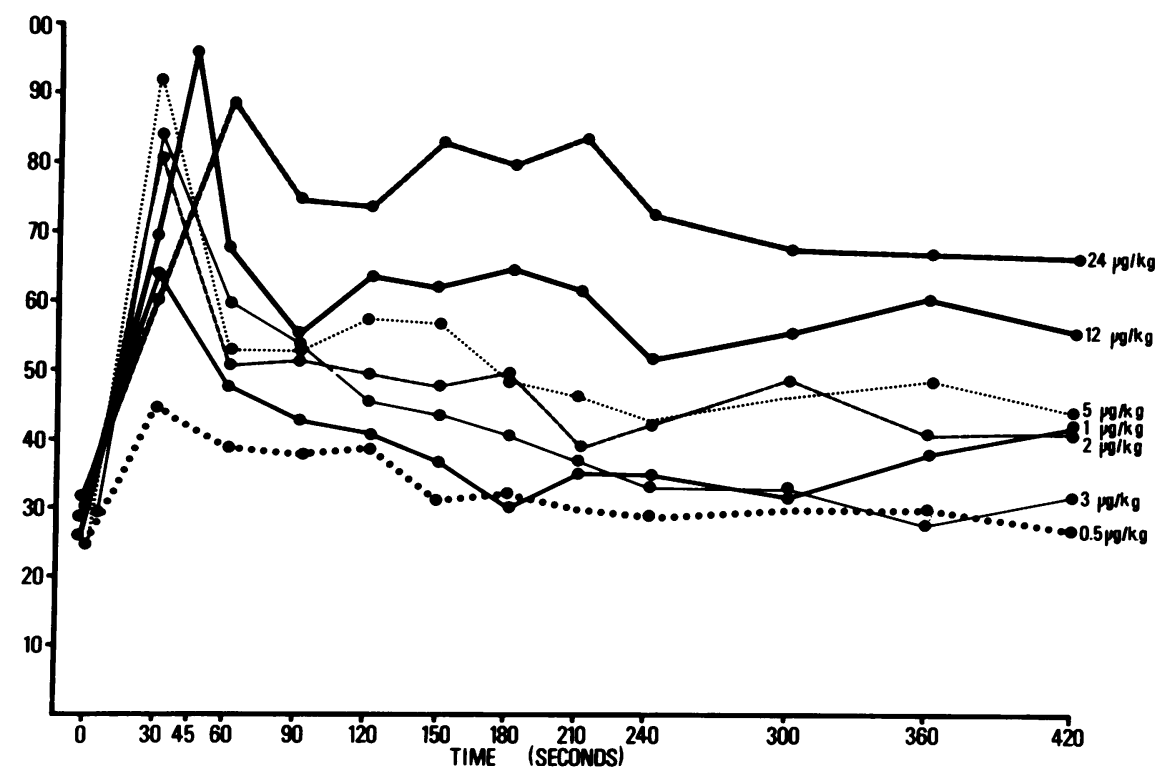

FIgURE 4 The effect of an i.v. bolus of methacholine on LES pressure. Each point is the mean of 21 studies. Methacholine resulted in a maximal effect after 30-60 s. An increasing response to dose increments up to $12 \mu \mathrm{g} / \mathrm{kg}$ was observed. 


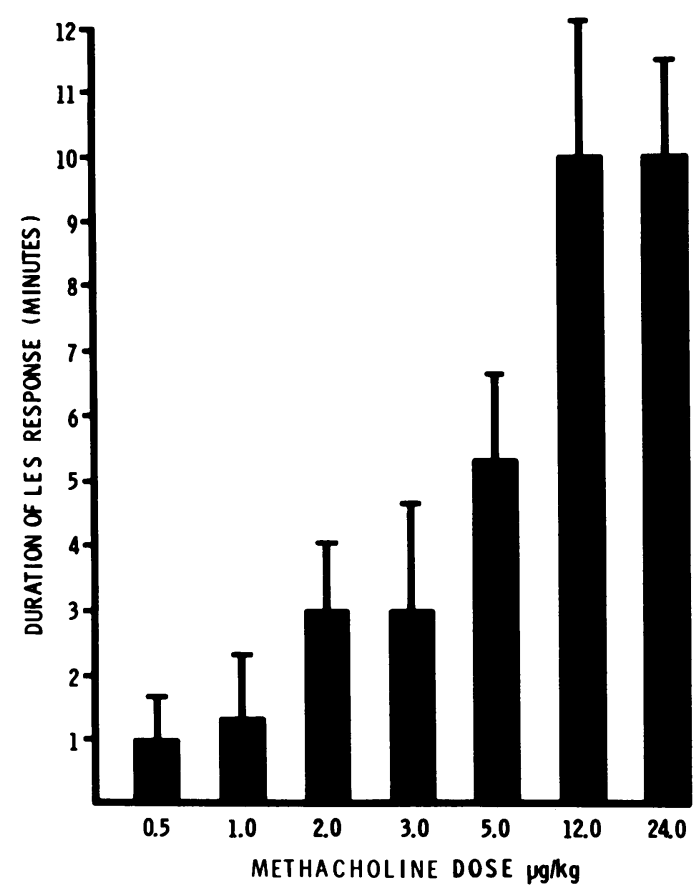

FIGURE 5 Time for LES resting pressure to return to $150 \%$ of basal level after an i.v. bolus of methacholine (mean \pm SD). Duration of effect progressively increased with dose increments up to $12 \mu \mathrm{g} / \mathrm{kg}$.

If pentagastrin excited the LES by releasing acetylcholine from postganglionic cholinergic neurons, blockade of muscarinic receptors with atropine should unmask a pure inhibitory response to pentagastrin at higher doses. Atropine in moderate or extremely high doses lowered resting sphincter pressure by $50 \%$, but did not block the stimulatory effect of low doses of pentagastrin on the LES, nor did it convert the action of higher doses to inhibition. The peak effect of $2 \mu \mathrm{g} / \mathrm{kg}$ pentagastrin was slightly reduced after $50-100 \mu \mathrm{g} / \mathrm{kg}$ of atropine but inhibition was not observed after 500 $2,000 \mu \mathrm{g} / \mathrm{kg}$ of atropine. The peak response to $6 \mu \mathrm{g} / \mathrm{kg}$ of pentagastrin was diminished but not blocked by moderate doses of atropine. High doses of atropine did not significantly diminish peak responses to pentagastrin, but significantly prolonged them. These results demonstrate that only a small portion of pentagastrin's excitatory effect on the LES is mediated by an atropine-sensitive cholinergic neuron. A direct effect on the LES musculature appears to be the major mechanism by which pentagastrin increases sphincter pressure. If so, this suggests a different mechanism of action for pentagastrin on LES in dogs than that suggested by Lipshutz et al. (11) in the opossum for gastrin; this might be due to species difference or a difference between experiments in vivo and in vitro. It is probably not due to the use of pentagastrin in this study in vivo in contrast to the use of gastrin in the study of opossum LES in vitro, since both act on similar receptors in all studies to date. A more remote possibility is that pentagastrin's stimulatory action is not directly on smooth muscle but on receptors in nerves that are not atropine-sensitive. Such nerves have been described in the dog (12). These excitatory effects could not be the "rebound" observed after inhibition of various gut muscles $(13,14)$; there was no prior inhibition.

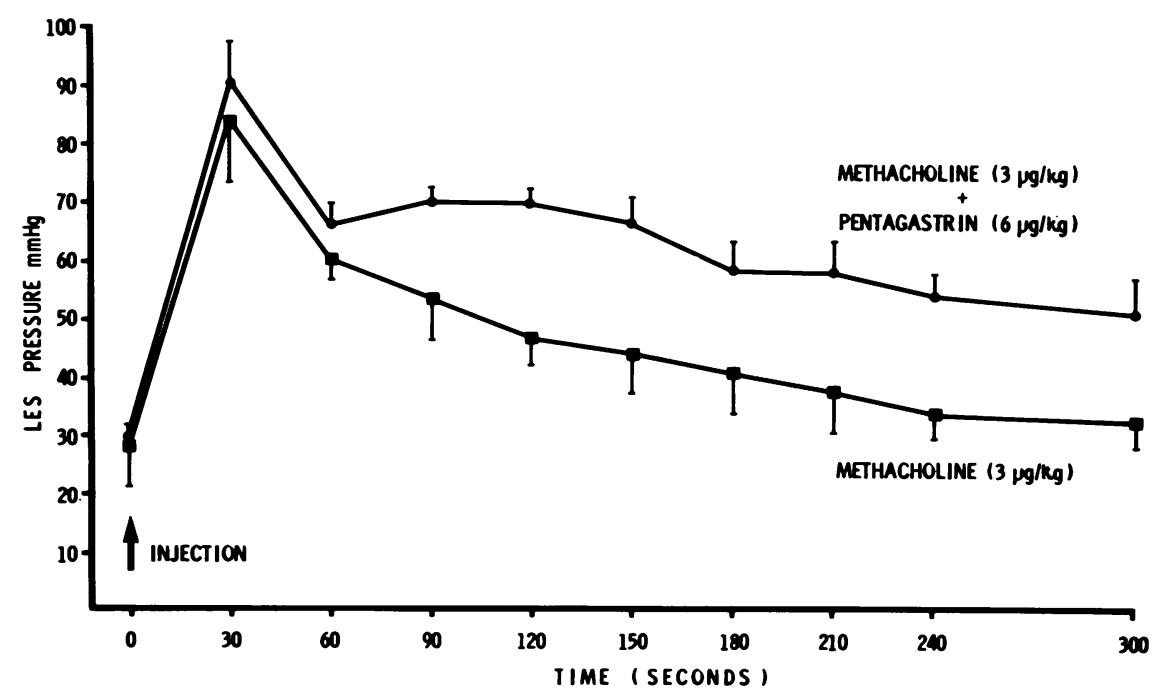

FIGURE 6 The effect of a combined i.v. bolus of methacholine and pentagastrin on LES resting pressure. Each point represents the mean \pm SEM of 12 studies. An inhibitory dose of pentagastrin had no effect on maximal response to $3 \mu \mathrm{g} / \mathrm{kg}$ i.v. bolus of methacholine. It did, however, prolong the response $(P<0.05$ at all points after $90 \mathrm{~s})$.

1648 R. Zwick, K. L. Bowes, E. E. Daniel, and S. K. Sarna 


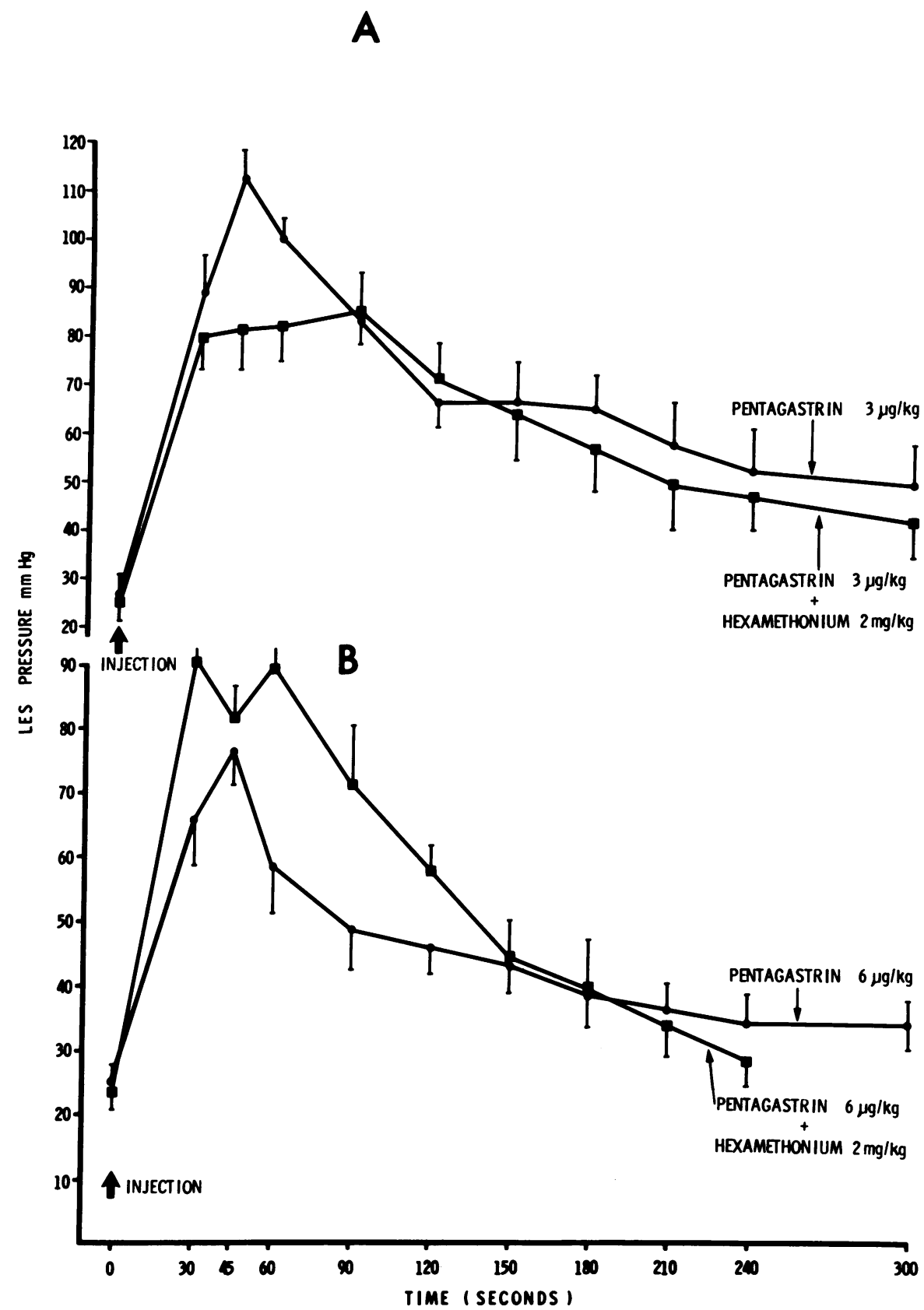

FIGURE 7 A. The effect of hexamethonium $(2 \mathrm{mg} / \mathrm{kg})$ on the response of LES resting pressure to an i.v. bolus of pentagastrin $(3 \mu \mathrm{g} / \mathrm{kg}$ ) (mean \pm SEM). Hexamethonium significantly diminished the peak response of the LES to $3 \mu \mathrm{g} / \mathrm{kg}$ of pentagastrin $(P<0.01)$. B. The effect of hexamethonium $(2 \mathrm{mg} / \mathrm{kg})$ on the response of the LES resting pressure to an i.v. bolus of pentagastrin $(6 \mu \mathrm{g} / \mathrm{kg}$ ) (mean $\pm S E M)$. Hexamethonium resulted in a slightly longer response of the LES to $6 \mu \mathrm{g} / \mathrm{kg}$ of pentagastrin $(P<0.05$ at $60 \mathrm{~s}$ and $<0.025$ at 90 and $120 \mathrm{~s})$.

Atropine in large doses did not reduce but augmented slightly the response of the LES to $2 \mu \mathrm{g} / \mathrm{kg}$ of pentagastrin and decreased the secondary inhibition after $6 \mu \mathrm{g} / \mathrm{kg}$ of pentagastrin. If atropine in these doses acted selec- tively to block actions of muscarinic agonists, these results and those with methacholine suggest that pentagastrin in high doses acted at a nonsmooth muscle site as well as directly; i.e. to stimulate inhibitory neurons 


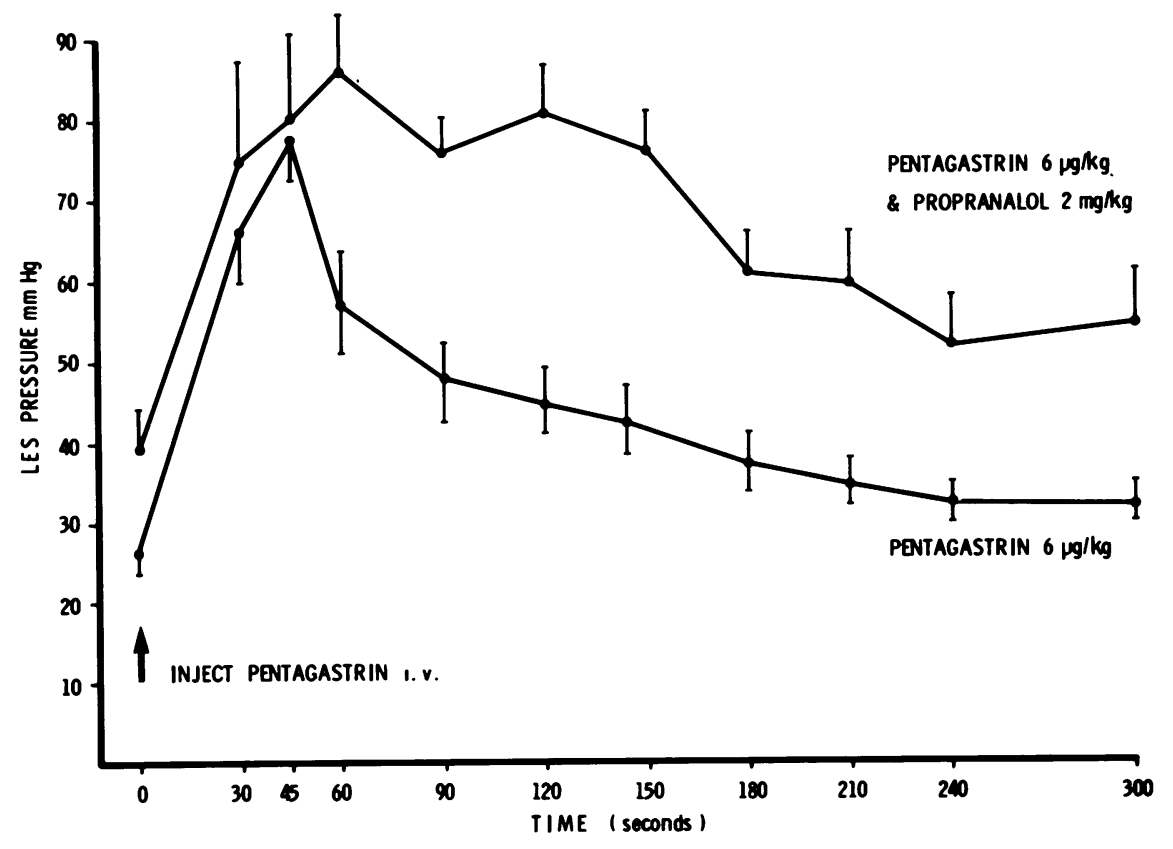

FIGURE 8 The effect of propranolol $(2 \mathrm{mg} / \mathrm{kg})$ on the LES response to an i.v. bolus of pentagastrin $(6 \mu \mathrm{g} / \mathrm{kg})$ (mean $\pm S E M)$. Propranolol had no effect on the peak response of the LES to $6 \mu \mathrm{g} / \mathrm{kg}$ pentagastrin. It did, however, result in considerable prolongation of the effect $(P<0.01$ at all points after $60 \mathrm{~s})$.

with muscarinic receptors as well as excite smooth muscle. The failure of high doses of methacholine to inhibit LES pressure rules out the peripheral muscarinic receptors as the site of its inhibitory action. However, hexamethonium also increased and prolonged responses to large doses of pentagastrin. Thus, there probably were both muscarinic and nicotinic receptors on those neurons capable of being activated by pentagastrin. Goyal and Rattan presented evidence for the existence of inhibitory ganglia with nicotinic and muscarinic receptors that supplied inhibitory nerves to the LES in the opossum (15). Our work generally supports this concept, but a serious difficulty remains; why did methacholine not stimulate these ganglionic muscarinic receptors? No good answer is available.

Hexamethonium significantly diminished the peak response of the LES to an i.v. bolus of $3 \mu \mathrm{g} / \mathrm{kg}$ of pentagastrin. This small inhibitory effect was similar to that observed with small doses of atropine and suggests that the small neurally mediated excitatory component of pentagastrin's action is due to a preganglionic site of action, as suggested for the dog's stomach (10). If pentagastrin releases acetylcholine from preganglionic neurons then it might, in sufficient doses, release enough to affect the vagally innervated inhibitory neurons that relax the LES (15). Thus, a dual action of pentagastrin would not be surprising. Furthermore, the dual action of atropine at low and high doses is understandable in light of this possibility: low doses might diminish the peak response to pentagastrin by inhibiting the action in the LES of acetylcholine released by an action on neural receptors, higher doses might prolong the responses to high doses of pentagastrin by inhibiting muscarinic receptors in ganglia involved in transmission of inhibitory activity to the LES. Goyal and Rattan (15) have found evidence for such receptors in vagally innervated ganglia, causing inhibition of the opossum LES. They also found evidence of nicotinic receptors on these ganglia. Thus, hexamethonium should have complex actions, inhibiting transmission of the small excitatory effects of low doses of pentagastrin and partially inhibiting, in addition, the inhibiting preganglionic effects of high doses of pentagastrin. Our results are consistent with such variety of effects from hexamethonium: decreased peak response to low doses of pentagastrin, peak effects slightly prolonged but not increased in response to higher doses of pentagastrin.

High doses of atropine potentiated the peak responses to low but not to high doses of pentagastrin. Potentiation of the response to low doses implies that inhibitory effects of pentagastrin inhibited by atropine was greater than the excitatory effect. Therefore, at higher doses of pentagastrin that produced smaller peak responses, because of increased inhibitory effects according to our hypothesis, a greater potentiation of peak responses was expected after atropine but not found. Our data do not 
permit a conclusion about this paradox; however, we think it probable either that atropine was unable to block inhibitory effects of large doses of pentagastrin in the inhibitory ganglia of the esophagus or that a different adrenergic mechanism of inhibition of the LES was also activated.

DiMarino and Cohen (16) reported that noradrenaline release and sympathetic stimulation contributed to increased sphincter pressure in the opossum. Propranolol, a beta-adrenergic blocking agent, prolonged the effect of pentagastrin on the dog LES. An ultimate effect of pentagastrin on beta-adrenergic receptors seemed to be responsible for much of the shortened duration of stimulation with large doses of pentagastrin. Whether this inhibitory effect is due to an effect of pentagastrin on a beta-adrenergic process additional to that in the inhibitory neuron acted on by atropine and hexamethonium remains a matter of conjecture. It is possible that atropine and hexamethonium partly inhibit the excitatory response of the LES by inhibiting activation of sympathetic neurons; if so, the inhibitory effects of large doses of pentagastrin might result from release of enough noradrenaline to overflow to the beta receptors of the LES muscle.

This study indicates that the mechanism of action of pentagastrin on the LES in dogs is much more complicated than previously thought. Low doses have mainly stimulatory actions. The stimulatory effect of pentagastrin appears to be mainly by direct action on the LES, but a lesser stimulatory effect may involve an action on preganglionic cholinergic or adrenergic neurons. Higher doses have both stimulatory and inhibitory effects. The inhibitory process appears to be partly mediated through beta-adrenergic receptors. On the other hand, it seems to be partly at a preganglionic site mediated by acetylcholine release onto autonomic ganglia with both muscarinic and nicotinic ganglionic receptors.

\section{ACKNOWLEDGMENTS}

This work was supported by the Medical Research Council of Canada.

\section{REFERENCES}

1. Cohen, S., W. Lipshutz, and W. Hughes. 1971. Role of gastrin supersensitivity in the pathogenesis of lower esophageal sphincter hypertension in achalasia. J. Clin. Invest. 50: 1241-1247.
2. Lipshutz, W., R. D. Goskins, W. M. Lukash, and J. Sode. 1973. Pathogenesis of lower esophageal sphincter incompetence. N. Engl. J. Med. 289: 182-184.

3. Isenberg, J., A. Csendes, and J. H. Walsh. 1971. Resting and pentagastrin-stimulated gastroesophageal sphincter pressure in patients with Zollinger-Ellison syndrome. Gastroenterology. $61: 655-658$.

4. Jennewein, H. M., F. Waldeck, and K. Prahl. 1972. Zur Beeinflussung des unteren Osophagussphinckters durch gastrointestinale Hormone beim Hund. Leber Magen Darm. 2: 17-19.

5. Lipshutz, W., and S. Cohen. 1971. Physiological determinants of lower esophageal sphincter function. Gastroenterology. 61 : 16-24.

6. Cohen, S., and W. Lipshutz. 1971. Hormonal regulation of human lower esophageal sphincter incompetence: interaction of gastrin and secretin. J. Clin. Invest. 50: 449-454.

7. Gregory, R. A., and H. J. Tracy. 1964. The constitution and properties of two gastrins extracted from hog antral mucosa. Gut. $5: 103-117$.

8. Bennet, A. 1965. Effect of gastrin on isolated smooth muscle preparations. Nature (Lond.). 208: 170-173.

9. Cook, M. A., K. Kowalewski, and E. E. Daniel. 1974. Electrical and mechanical activity recorded from the isolated perfused canine stomach: The effects of some G. I. polypeptides. Proceedings of the Fourth International Symposium on Gastrointestinal Motility. Mitchell Press, Ltd., Vancouver, B. C. 233-241.

10. Vizi, S. E., G. Bertaccini, M. Impicciatore, and J. Knoll. 1973. Evidence that acetylcholine released by gastrin and related polypeptides contributes to their effect on gastrointestinal motility. Gastroenterology. 64: 268-277.

11. Lipshutz, W., A. F. Tuch, and S. Cohen. 1971. A comparison of the site of action of gastrin 1 on the lower esophageal sphincter and antral circular smooth muscle. Gastroenterology. 61: 454-460.

12. Ambache, N., and M. A. Freeman. 1968. Atropine-resistant longitudinal muscle spasms due to excitation of non-cholinergic neurons in Auerbach's plexus. J. Physiol. (Lond.). 199: 705-727.

13. Bennett, M. R. 1966. Rebound excitation of the smooth muscle cells of the guinea-pig taenia coli after stimulation of intramural inhibtory nerves. J. Physol. (Lond.). 185: 124-131.

14. Furness, J. B. 1971. Secondary exctation of intestinal smooth muscle. Br. J. Pharmacol. 41: 213-226.

15. Goyal, R. K., and S. Rattan. 1975. Nature of the vagal inhibitory innervation to the lower esophageal sphincter. J. Clin. Invest. 55 : 1119-1126.

16. DiMarino, A. J., and S. Cohen. 1974. The adrenergic control of lower esophageal sphincter funciton. Proceedings of the Fourth International Symposium on Gastrointestinal Motility. Mitchell Press, Ltd., Vancouver, B. C. $623-629$. 